\title{
ジオグリッドの粘性による 時間依存変形強度特性
}

\author{
篠田昌弘 1 ・Richard, J. Bathurst ${ }^{2}$ ・龍岡文夫 3 ・堀井克己 1
}

\begin{abstract}
補強土構造物の設計上の不確実性の1つとして、耐用年数を通した土中での補強材の時間依存変形特性があ る。補強材の粘性による時間依存変形特性を把握するために、ポリプロピレン、ポリエステル、高密度ポリェ チレンを用いて、34本のクリープ及び応力緩和試験を様々な引張荷重で24時間行い、その後に引張り試験を行 い強度を測定した。画像解析により変形を測定した。実験の結果、クリープ変形や応力緩和を経験した後でも、 同一の試験条件（ひずみ速度等）の下では補強材の引張強度は低下しておらず、地震時の補強材の設計強度を 設定する際にクリープ低減保数を考慮すると補強材の引張強度を過小評価することが分かった。
\end{abstract}

キーワード :クリープ, リラクセーション，ジオグリッド，画像解析

\section{1. はじめに}

ジオシンセティクスは土の変形特性に関する潜在的な 欠点を補うために、世界的に普及してきている。特に盛 土や基礎地盤においてもその利用は拡大の一途を辿って いる。土とジオシンセティックスの相互作用は設計や施 工で考慮されるべき基本的メカニズムである。その複雑 な相互作用を把握するために、非常に多くの引き抜き試 験や引張り試験が行われている。

ジオシンセティックスの引張試験は、気中試験と土中 試験がある。ジオシンセティックスは盛土内部に埋設さ れるため、変形強度特性が拘束圧に影響されるので、こ のジオシンセティックスの引張試験は、拘束圧下で行う 必要がある ${ }^{1,2}$ 。気中試験は、拘束圧に依存しないジオ シンセティックスの設計上での引張り特性を求めるもの である。また、気中引張り試験には試験が容易に行える という利点がある。本報告では、変形強度特性が拘束圧 に影響を受けないジオシンセティックスの気中試験行い、 ジオシンセティックスの変形強度特性について検討した。 欧米の補強土構造物設計法では、Creep nupture curve ${ }^{334)}$ もしくは Isochronous load-strain curve ${ }^{3 / 390}$ を利用して補強材 の設計強度を決定している。しかしながら、長期に渡つ て盛土内に埋設されたジオグリッドを取り出し、同じひ ずみ速度で引張り強度を測定した結果、初期状態での (時間依存変形を経験していない) ジオグリッドの引張 り強度とほぼ同じ值を示したという報告がある。これは、 常時荷重条件にあるジオシンセティックスに地震荷重な どの大きな外的荷重が加わった際の引張り強度は、クリ 一プの履歴を受けていない引張り強度とほほ等しいこと

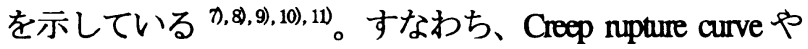
Isochronous load-strain curveに基づいて設計引張り強度（特 に地震時の）を決定する方法は適切ではないことを示唆 している。また、この点からのジオシンセティックスの 時間依存変形特性に関する研究が必要であることを示し ている。

ジオグリッドの粘性による時間依存変形特性を把握 するためには、一定荷重下での引張り試験（クリープ試 験) や、一定伸び下での引張り試験（応力緩和試験）が 重要である。しかしながら、欧米や日本の補強土構造物 設計法では、ジオグリッドのクリープ変形のみを考慮し ているが、応力緩和現象の可能性とその影響は無視して

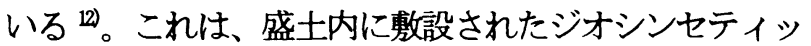
クスの張力の測定が技術的には非常に難しく、応力緩和 現象が把握できないことに起因している。この設計法は 安全側ではあるものの、現実の盛土内に埋設されたジオ グリッドには盛土の変形に応じた応力緩和現象がある可 能性が高い 12), 13)。したがって、クリープ変形だけを考慮 して補強土構造物の変形を予測すると、変形を過大に見 積もり不経済となる可能性がある。しかしながら、ジオ グリッドの応力緩和試験はこれまで殆どなされていない。

本研究では、ジオグリッドの粘性による時間依存変 形特性と強度特性を調べるために、気中において様々な 長さ、幅、ひずみ速度で引張り試験を行った。ジオグリ ッドのひずみ測定には、伸びひずみと伸びひずみに直交 する水平ひずみを同時に測定できる新しいシステムを導 入した。クリープ試験と同時にリラクセーション試験も 行った。さらに、クリープ低減係数の妥当性を検討する ために、クリーブ試験と応力緩和試験後のジオグリッド

1正会員，（株）複合技術研究所，技術部，（广107-0052 東京都港区赤坂神田2-15-16 赤坂ふく源ビルTF）， ${ }^{2}$ Member of IGS， GeoEngineering Centre at Queen's-RMC, Civil Engineering Department, Professor, Royal Military College of Canada, Kingston, Ontario, K7K 7B4,Canada，3正会員，東京大学工学部土木工学科,教授，（广113-8656 東京都文京区本郷7-3-1）. 
を用いて、一定のひずみ速度での引張り強度を測定した。

\section{2. ジオグリッド供試体}

ポリエステル（以下 PET）、ポリプロピレン（以下 PP）、高密度ポリエチレン（以下 HDPE）を用いた。表 1 に用いたジオグリッドの物性と変形強度特性を示す。 PP と PET は、実際の現場で使用されるものより低い引 張り強度を持つものを用いた。これは、引張り試験の容 易さに加え、ジオグリッドの時間依存変形特性を明確に 捉えるためである。一方でより現実的な挙動を把握する ために、他のジオグリッドと比べ比較的大きい引張り強 度を持つHDPEを使用した。

ポリマーの種類や厚さ、リブの数や間隔などの様々 な物性や形状によって、引張り挙動は異なってくる。織 布や不織布では、試験供試体の形状が引張り特性に与え る影響を検討するために、様々な縦横比で引張り試験が 実施され、維横比が $1: 2$ の割合が最もネッキングの影響 が少なく適切であるとの報告がある ${ }^{1219}$ 。 ASTM D 4595 においてもジオテキスタイルの引張り試験においては、 幅 $200 \mathrm{~mm}$ 、クランプ間の長さ $100 \mathrm{~mm}$ の供試体を用いる ように指導している。しかしながら、ジオグリッドの形 状を変えた引張り試験はほとんど報告されておらず、ジ オグリッドの形状が引張り特性に与える影響は明確では ない。したがって、本研究ではジオグリッドの形状を変 えて引張り圾験を行い、ジオグリッドの形状が引張り特 性に与える影響も調べた。

\section{3. 載荷装置及び測定装置}

\section{（1）載荷装置}

油圧式のアクチュエーターを備えた載荷装置を用いて 引張り試験を行った。載荷枠は高さ $3.5 \mathrm{~m}$ 、幅 $1.2 \mathrm{~m}$ であ り載荷能力は $100 \mathrm{kN}$ である。最大ストロークは、 $160 \mathrm{~mm}$ であり、破断が生じない場合はこの最大ストロ ークで実験を終了した。

表 1 ジオグリッドの物性及ひ変形強度特性

\begin{tabular}{|c|c|c|c|}
\hline 基布素材 & $\mathbf{P P}$ & PET & HDPE \\
\hline 構造 & punched sheet drawn & knitted & Integrally formed \\
\hline 表面素材 & NA & PVC & NA \\
\hline 重量 $\left(\mathrm{g} / \mathrm{m}^{2}\right)$ & 215 & 114 & NA \\
\hline \multicolumn{4}{|l|}{ 開き目 (mm) } \\
\hline 繸方向 & 25 & 27 & NA \\
\hline 横方向 & 33 & 22 & NA \\
\hline \multicolumn{4}{|l|}{ 厚さ (mm) } \\
\hline ㅈララド & 1.0 & 1.1 & 1.0 \\
\hline 交点 & 2.9 & 1.2 & 2.7 \\
\hline \multicolumn{4}{|c|}{ 引張強度 $(\mathrm{kN} / \mathrm{m})$} \\
\hline 5\%ひずみ & 8.3 & 4.4 & 35.7 \\
\hline 最大値 & 125 & 17.5 & 68.9 \\
\hline
\end{tabular}

Notes: NA: Not applicable; PP: Polypropylene; PET: Polyester, HDPE: High density polyethylene; PVC: Polyvinyl chloride.

\section{（2）画像解析による变形測定手法}

様々な種類のジオシンセティックスを用いて変形特性 を実験的に検討する際には、測定誤差が結果に影響を及 ぼさないことが必要不可欠である。比較的剛な材料の引 張り試験を行う際には、一般的に、外部変位計やひずみ ゲージを補強材に設置して引張りひずみの測定を行って いる。これらの測定装置は、その重さや取り付け方法の 難しさなどから、しばしば不安定な結果をもたらす。最 近では、非接触式変位計、例えばギャップセンサーやレ 一ザー変位計も開発されてはいるものの、測定方向は一 方向のみであり、測定方向を増やす場合には、測定装置 を増やす必要がある。様々な方向を同時に測定できる手 法として、Leshchinsky and Fowler (1990) ${ }^{17}$ が報告した写真 撮影による画像解析手法があるが、人力に頼るところが あり実際には、技術的時間的に難しい。

本研究で用いられた画像解析による自動計測システ ムは、上記の問題点を克服したものである。最大計測周 波数は、 $25 \mathrm{~Hz}$ であり、測定精度は約 $0.4 \mu \boldsymbol{m}$ である。Jones $(2000)^{18)}$ は、この画像解析手法を用いて3種類のジオテキ スタイルの引張り試験を行い、一般的に使用されている 外部変位計で得られた引張りひずみの值と比較した。実 験の結果、画像解析による引張りひずみ測定手法の利便 性、妥当性を示した。しかしながら、Jones (2000) $)^{18)}$ はそ の画像解析手法を用いたクリープや応力緩和試験は行っ ていない。本検討では、画像解析による自動計測システ ムを用いてクリープや応力緩和を含めたジオシンセティ ックスの引張り試験を実施し、画像解析手法の妥当性を 明らかにした。

\section{(3) ローラークランプ}

ローラークランプ (図1a) は、しばしば高強度のジオ シンセティックスの引張り試験に用いられる17,19)。ロー ラークランプの主な利点はジオシンセティックスのクラ ンプへの容易な取り付けである。ASTM D 4595 $5^{16)}$ では口 ーラークランプの性能は認めてはいるものの、引張り荷 重が増加するにつれてローラーまわりでの供試体の滑り 量の増加を指摘しており、クランプ間の距離で計算され た実際のひずみ速度と適切に測定されたひずみ速度の相 違を指摘している。したがって、ローラークランプを使 用して引張りひずみを測定する場合、クランプ間に外部 変位計、非接触変位計、ひずみゲージなどの測定装置を 設置し測定を行う必要がある。本検討では、引張りひず みの伸び方向とその直角方向を同時に測定できる画像解 析手法を用いて引張り試験を実施した。

\section{4. 実験方法}

無拘束圧下でのジオグリッドの引張り試験は以下の ような手順で行った。まず、供試体の緩みを極力除きな がら供試体をクランプのローラーに巻き付け、供試体を 載荷装置中心にセットする。画像解析を用いて事前に行 
った予備試験の結果、PPとPETジオグリッドでは、供試 体中心付近で変形が一様であるが、HDPEジオグリッド は伸びひずみ分布が一様ではなく、引張り試験の際のひ ずみを測定する際には注意を要する必要があることが分 かった。よって、画像解析のターゲットとして、PPと PETジオグリッドに関しては、供試体中心のリブの交点 上に3個のターゲット（図1b、1cのa点、b点、c点）を設 定した。HDPEジオグリッドでは、供試体の大きさから すべてのターゲットを交点には設定できないので、リブ の交点と縦ストランド上にターグットを6個（図1d 点 〜 f点）設置した。初期の供試体の緩みを除くために、 初期荷重として0.187 kNの引張り力を加えてから、そこ で引張りひずみのゼロ点をとり、引張り試験を開始した。

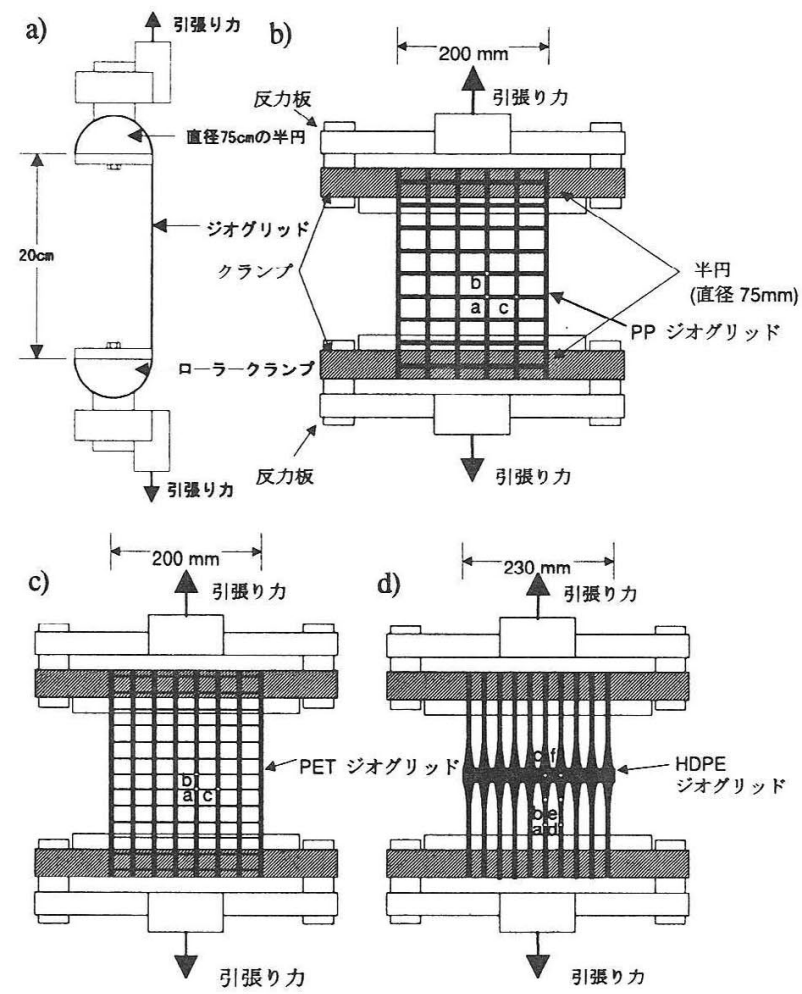

図1引張り試験概略図 : a) 側面図,b) 正面図 (PP),c) 正面図 (PET),d)正面図 (HDPE)

PP、PET、HDPEの変形特性を把握するために、様々 な形状とひずみ速度で以下のような試験を行った。

\section{（1）再現性を確認するための単調載荷試験}

本検討で用いられた全てのジオグリッドに対して、同 じ定ひずみ速度 $10 \% / \mathrm{min}$ で引張り試験を3回行った。

\section{（2）ジオグリッドの形状を変化させた単調載荷試験}

(1) PPとPETの供試体の長さのみを変化させて合計8本 引張り試験を行った。供試体の長さは、PPの場合、 $224 \mathrm{~mm}, 314 \mathrm{~mm}, 432 \mathrm{~mm}, 540 \mathrm{~mm}$ であり、PETの場合、 $226 \mathrm{~mm}, 286 \mathrm{~mm}, 395 \mathrm{~mm}, 496 \mathrm{~mm}$ であり、幅はどれも $200 \mathrm{~mm}$ である。
(2) PP供試体では、一定長さにおいて引張り方向のリブ の数を2, 4, 5, 6 と変化させて定ひずみ速度で引張り 試験を行った。PET供試体では、引張り方向のリブ の数を2, 4, 6, 8 とした。HDPE共試体では、引張り方 向のリブの数を $2,4,6,8,9,10$ とした。

\section{（3）定ひずみ速度単調載荷試験}

PP、PET、HDPE供試体にひずみ速度を $0.1 \% / \mathrm{min}$, $1.0 \% / \mathrm{min}, 10 \% / \mathrm{min}$ and $100 \% / \mathrm{min}$ として破断するまで単調 載荷試験を行った。

\section{（4）様々なひずみ速度における載荷試験}

PP、PET、HDPE供試体に対して、ひずみ速度を $0.1 \%$, $1.0 \%, 10 \%$ と変化させて連続的に載荷を行った。

\section{(5) クリープ試験}

PPジオグリッドを $05 \mathrm{kN} / \mathrm{min}$ で所定の引張り荷重まで 載何した後に、引張り強度の $10 \%, 25 \%, 37 \%, 50 \%, 60 \%$, 75\%でクリープ試験を行った。

\section{(6) 応力緩和試験}

それぞれのジオグリッドを所定の引張り力まで載荷 した後に、PP ジオグリッドでは、引張り強度の $21 \%$, $41 \%, 54 \%, 62 \%, 69 \%, 72 \%$ でリラクセーション試験を 24 時間行った。PET ジオグリッド、HDPE ジオグリッドで は、それぞれ引張り強度の $24 \%, 37 \%, 46 \%, 54 \%, 75 \%$ 及 び22\%,35\%,40\%,58\%,74\%で試験を開始した。

\section{(7) クリープ及び応力緩和試験後の単調載荷試験}

クリープ試験後に引張りカをゼロまで除荷し、載荷 装置を応力制御から変位制御に変更した後に、同じ供試 体を用いて定ひずみ速度 $10 \%$ min で破断まで単調載荷を 行った。応力緩和試験では、応力緩和後に連続的に定ひ ずみ速度 $10 \% / \mathrm{min}$ で破断まで単調載荷を行った。

\section{5. 実験結果}

\section{（1）定ひずみ速度試験の再現性}

高分子材料でできた補強材の物性のばらつきは、製 造過程で少なからず生じるものであり、それは引張り特 性にも大きな影響を与えることが一般的に知られている 20)。本研究においては、製造過程における供試体の物性 のばらつきを明確にするため、各ジオグリッドを一定の ひずみ速度 (10\%/min) で 3 回行い、引張り圾験の再現 性について検討を行った。

図 2 は定ひずみ速度 $10 \%$ /min で載荷した時の引張り力 一伸びひずみ関係であり、高い再現性を示している。上 記の試験結果から、PP、PET、HDPE ジオグリッドの平 均破断強度はそれぞれ、13.1 kN/m、16.6 kN/m、58.3 kN/m であった。これらの值は各メーカーから提出された值の $12.5 \mathrm{kN} / \mathrm{m} 、 17.5 \mathrm{kN} / \mathrm{m} 、 68.9 \mathrm{kN} / \mathrm{m}$ とほぼ等しく、引張り 
試験の妥当性が確認できた。

既往の研究などから、本研究で用いる平均破断強度 は、PP、PET ジオグリッドでは $13 \mathrm{kN} / \mathrm{m} 、 17 \mathrm{kN} / \mathrm{m}$ として、 HDPE ジオグリッドでは実験結果に基づいて $58 \mathrm{kN} / \mathrm{m}$ と した。これらの平均破断強度をクリープ荷重や応力緩和 を開始する荷重を決定する際の指標とした。

\section{（2）ジオグリッドの縦横比の影響}

a) 一定の幅で長さを変化

PPとPETジオグリッド供試体の幅を $200 \mathrm{~mm}$ で一定とし、 様々な長さで定ひずみ速度 $10 \% / \mathrm{min}$ で引張り試験を行っ た（図3）。HDPEジオグリッドは、載荷装置のストロー クの限界から、長さを変化させて試験を行うことが不可 能だったため、この検討ではHDPEは用いなかった。PP、 PETジオグリッドを用いて試験を行った結果、以下のよ うな挙動が観察された。

(1) 引張りカー伸びひずみ関係は、供試体長さを変化さ せても同様な挙動を示し、本実験で用いた供試体幅 200 mmにおけるPP、PETジオグリッドでは、供試体 長さが引張り強度に与える影響は小さい。

(2) PP、PETジオグリッドの平均引張り強度はそれぞれ $12.9 \mathrm{kN} / \mathrm{m} 、 17.3 \mathrm{kN} / \mathrm{m}$ となり、これらの值は製品基淮強度 である $12.5 \mathrm{kN} / \mathrm{m} 、 17.5 \mathrm{kN} / \mathrm{m}$ とほぼ等しい結果となった。

\section{b）一定の長さで幅を変化}

ジオグリッドの引張り特性に与える供試体幅の影響を 明確にするために、様々な供試体幅でPP、PET、HDPEジオ グリッドの引張り試験を行い、以下のような結果が得ら れた。

(1) PPジオグリッドの定ひずみ速度引張り試験を供試体 幅を変化させて行った結果、どの供試体でもほぼ同 じ引張り強度が得られた（図4a）。しかしながら、 最大引張りひずみは「幅200mmの供試体を用いた定 ひずみ速度試験」から得られた值よりも、大幅に小 さい。これは長手方向のリブ数が2〜5のジオグリッ ドでは、載荷に伴う大きなネッキング現象が現れな いため、最大引張りひずみが小さいと考えられる。 ネッキング現象の発生の原因については現在検討中 である。

(2) PETジオグリッドでは、供試体長さを変化させた実 験結果と傾向は同じである（図4a）。しかしながら、 長手方向のリブ数が2の引張り試験結果では、比較 的低い引張り剛性が示された。これは、クランプと 供試体とのすべりに起因するものと考えられる。

(3) HDPEジオグリッドに関しては、幅を変化させても 引張り特性はなんら変化せず、HDPEの引張り挙動 には幅は影響しないことが分かった（図4b）。

図5はPP、PET、HDPEを用いて様々な綐横比で行った定 ひずみ引張り試験結果をまとめたものである。図5には 参考のため、その平均值も同時にプロットした。PETと HDPEの最大引張りひずみに関しては、供試体の幅と長 さによる影響は無視できるが、PPジオグリッドに関し ては大きく影響を受けることが分かった（図5a）。
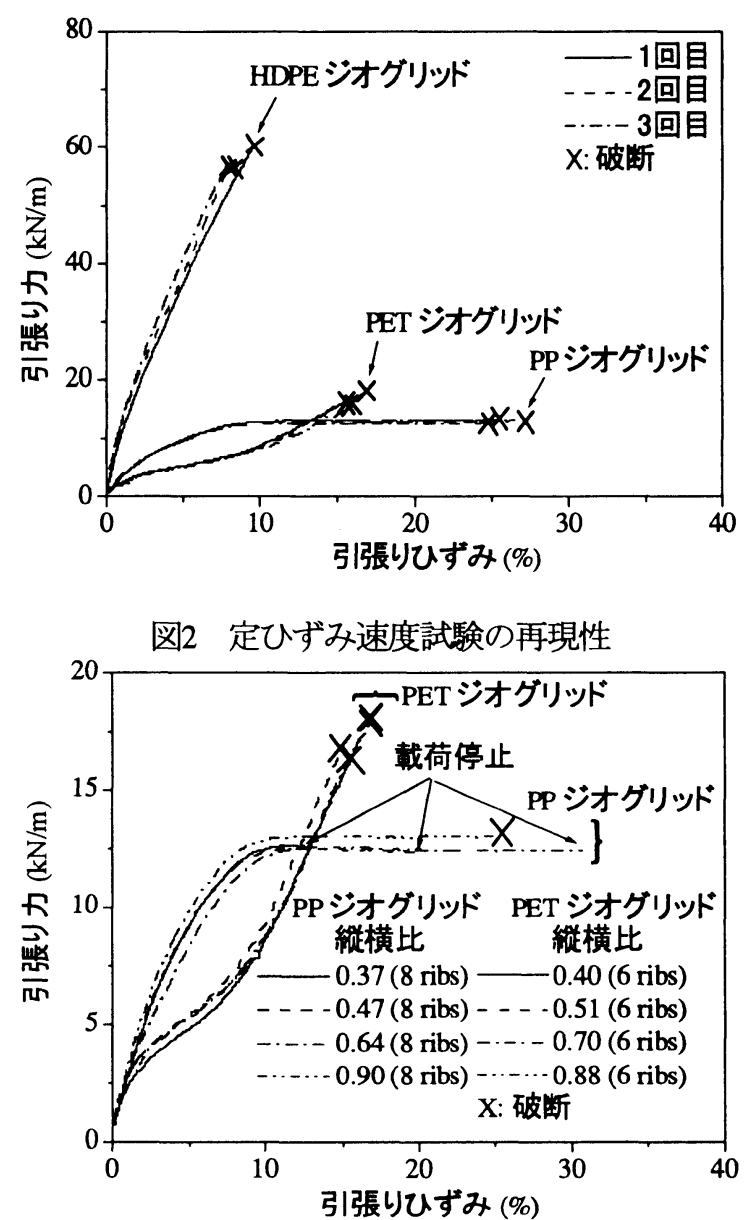

図3 一定幅で長さを変化させた定ひずみ速度試験
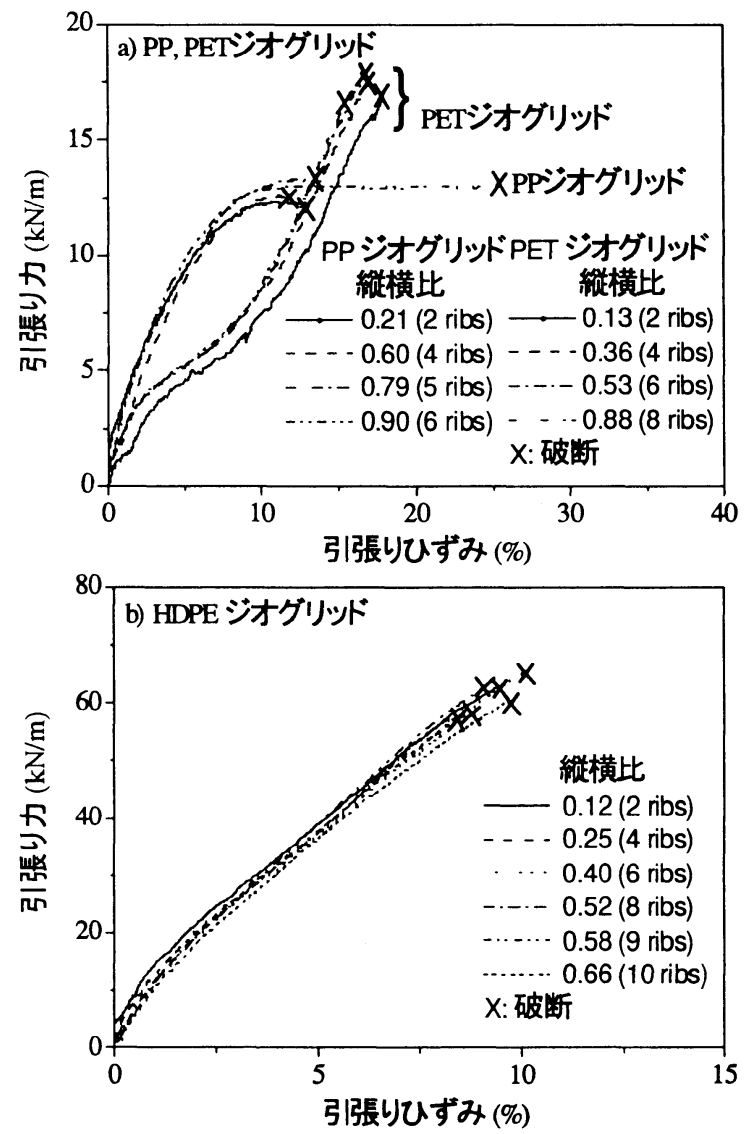

図4 一定長さで幅を変化させた定ひずみ速度試験 
引張り強度に関しては、PP、PET、HDPE とも若干の ばらつきはあるものの、供試体の幅と長さは引張り強度 には影響しないことが分かった（図 5b）。重要なこと に、PP と PET ジオグリッドの引張り強度に関しては、 実験結果のばらつきが非常に小さく、その平均值が製品 基準値とほぼ同值であったことである。

\section{（3）ひずみ速度の影響}

図 6 に、PP、PET、HDPE ジオグリッドの引張りカを 引張りひずみに対してプロットした。図6には、それぞ れのジオグリッドでひずみ速度を一定に保った試験と急 変させた引張り試験の結果を同時に示した。上記の実験 結果から、以下のようなことが分かった。

\section{a) PPジオグリッドを用いた引張り試験}

(1) PPジオグリッドの変形強度特性のひずみ速度依存性 はPET、HDPEジオグリッドよりも大きく、ひずみ 速度が上がるとピーク前の剛性と引張り強度が増加 した (図6a)。

(2) PPジオグリッドの最大引張りひずみは、ひずみ速度 が小さくなるほど大きくなった。これは、ネッキン グに起因するものであり、ひずみ速度が小さくなる とネッキングの程度が大きくなるためである。

b) PETジオグリッドを用いた引張り試験： PETジオ グリッドの変形強度特性に与えるひずみ速度の影響 は比較的小さかった（図6b)。

c) HDPEジオグリッドを用いた引張り試験

(1) HDPEジオグリッドの変形強度特性に与えるひずみ 速度の影響は、PPジオグリッドに次いで大きかった (図6c)。

(2) HDPEジオグリッドも、ひずみ速度が低いほど延性を 示した。これも、ネッキングに起因するものであり、 ひずみ速度が小さくなるとネッキングの程度が大き くなるためである。

\section{（4）クリープ試験}

ジオシンセティックスは、一定引張り荷重の下で時間 とともに連続的に伸びる。クリープ速度は、初期クリー プ、二次クリープ、三次クリープと分けられ、三次クリ 一プは、クリープ破壊に帰着するものであり、クリープ 速度は急激に増加する ${ }^{19}$ 。本研究では様々な一定引張り 荷重で PP、PET、HDPE ジオグリッドのクリープ試験を 行った。クリープ試験を行うにあたって、0.5 kN/min の 載荷速度でクリープ引張り荷重に達するまで荷重を連続 的に供試体に与えた。クリープ時間は便宜上、24 時間 と設定した。PP、PET、HDPE ジオグリッドのクリープ 試験結果を図 7 に示す。クリープ試験により、以下のこ とが分かった。

(1) PPジオグリッドは、一定荷重でPET、HDPEジオグ リッドよりもはるかに大きなクリープひずみを示し た後にクリープ破壊した (図7a)。

(2) PETジオグリッドのクリープ中の引張りひずみ量は 非常に小さかった（図7b）。非常に興味深いことに
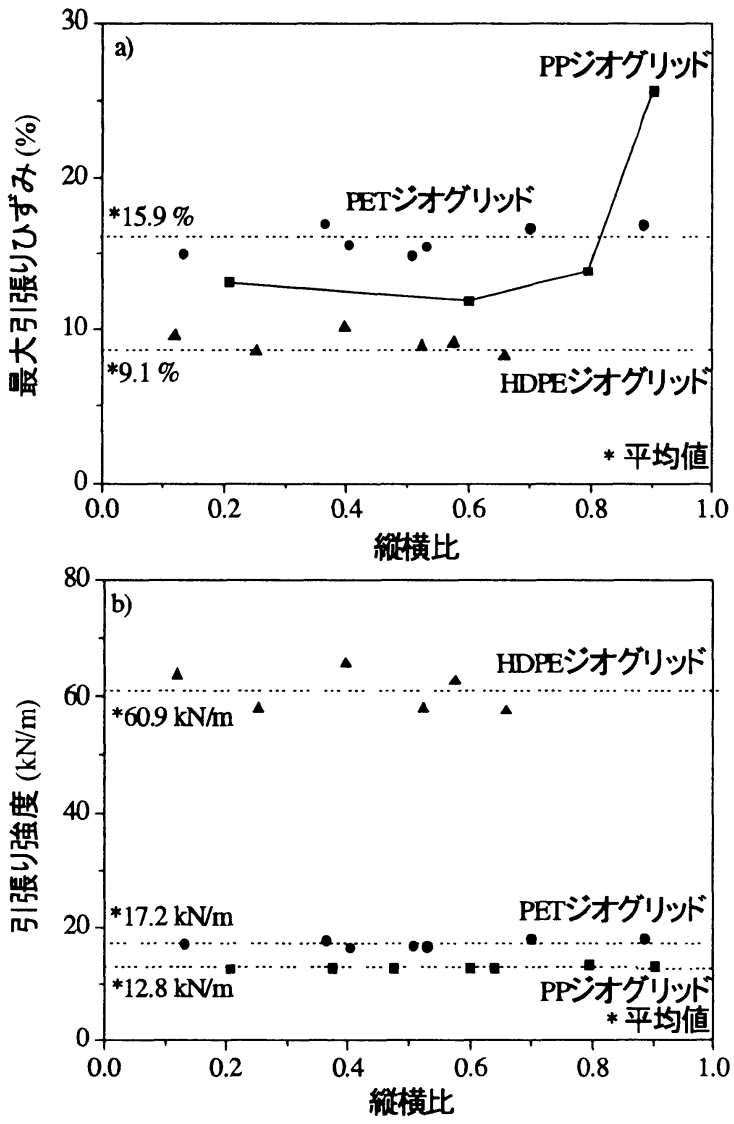

図5＼cjkstart縌横比を変化させた定ひずみ速度試験結果
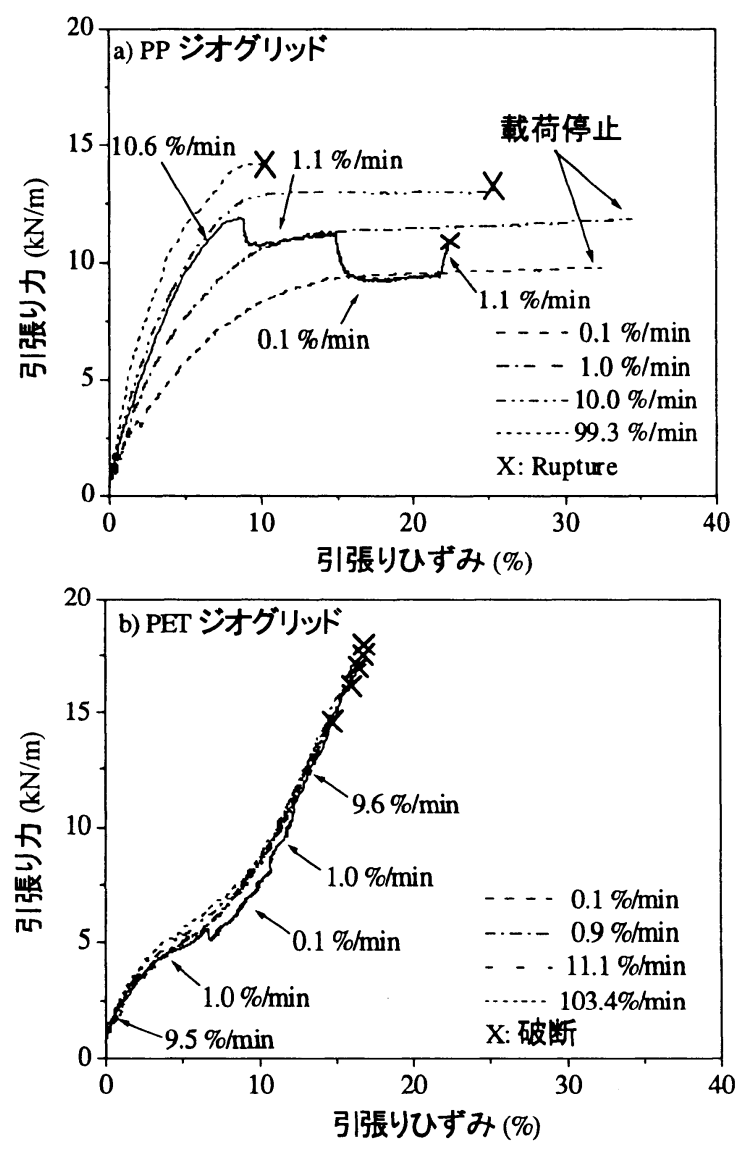

図6 定ひずみ速度試験及びひずみ速度を変化させた試 験 
PET ジオグリッドのクリープ中の引張りひずみは、 平均引張り強度の $10 \%$ の゙クリープ試験を除いて、 クリープ何重が大きくなるほど小さくなった。すな わち、平均引張り強度の $25 \%$ でのクリープ圾験が 最もクリープ中の引張りひずみが大きかった。これ は、PET ジオグリッドの接線剛性が載荷荷重の増加 に伴って増加することに起因するものである ${ }^{21}$ 。 Voskamp and Van Vliet (2001) $)^{21}$ によれば、この現象は 分子構造の変化によるとされている。

\section{（5）応力緩和試験}

応力緩和試験 6)，(2)，22，23),24) はクリープ試験と比較すると 殆ど行われていない。図 8 に、応力緩和試験中の引張り 力を平均引張り強度で除した值の時刻歷を示した。応力 緩和試験から、以下のことが分かった。

(1) 全てのジオグリッドにおいて、初期引張り荷重が小 さくても24時間後では応力緩和現象は収束しなかっ た (図8)。

(2) PPジオグリッドは他のジオグリッドと比較すると、 非常に大きな応力緩和量を示した（図8a)。

(3) PP、HDPEジオグリッドにおいて、初期引張り荷重 が大きいほど応力緩和現象が顕著であった（図8a, $8 c)$ 。

(4) PETジオグリッドは対数時間に対して線形に応力緩 和が生じた（図8b）。

\section{（6）クリープ及び応力緩和試験後の定ひずみ速度試験}

クリープ及び応力緩和後でのジオグリッドの引張り 特性を把握するために、定ひずみ速度 $10 \%$ /min でクリー プと応力緩和試験後のジオグリッドを用いて引張り試験 を行った。クリープ及び応力緩和試験後に行った定ひず み速度試験によるPP、PET、HDPEジオグリッドの引張 り強度は、クリープ・応力緩和試験を行わない試験体の 平均引張り強度とほぼ同じ值を示した（図9）。これら の結果は、クリープや忘力緩和の履歴は引張り強度を低 堿させる効果はないと結論できる。これは、既往の研究 結果とも整合する78,99119,11)。

\section{6. 結論}

PP、PET、HDPE の基本的な引張り挙動及び粘性による 時間依存性変形挙動を、定ひずみ速度試験、ひずみ速度 を急変させる試験、クリープ試験、応力緩和試験、クリ 一プ及び応力緩和後の定ひずみ速度試験を行うことによ り検討した。上記の試験の結果から、以下のような知見 を得た。

（1） PP、PET、HDPEを用いた定ひずみ速度試験により、 画像解析により供試体の変形を測定する今回の試 験法の高い再現性が確認できた。

(2) PP、PETジオグリッドの引張り強度には、供試体 の長さは影響しない。

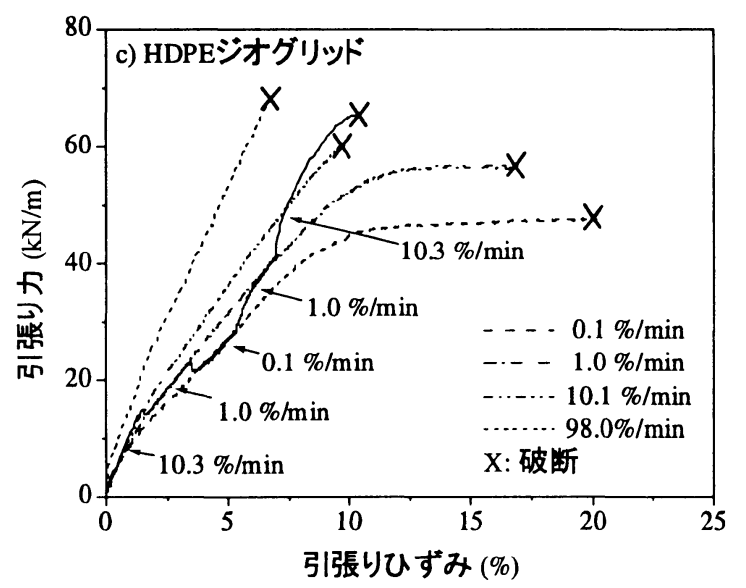

図6定ひずみ速度試験及びひずみ速度を変化させた試 験
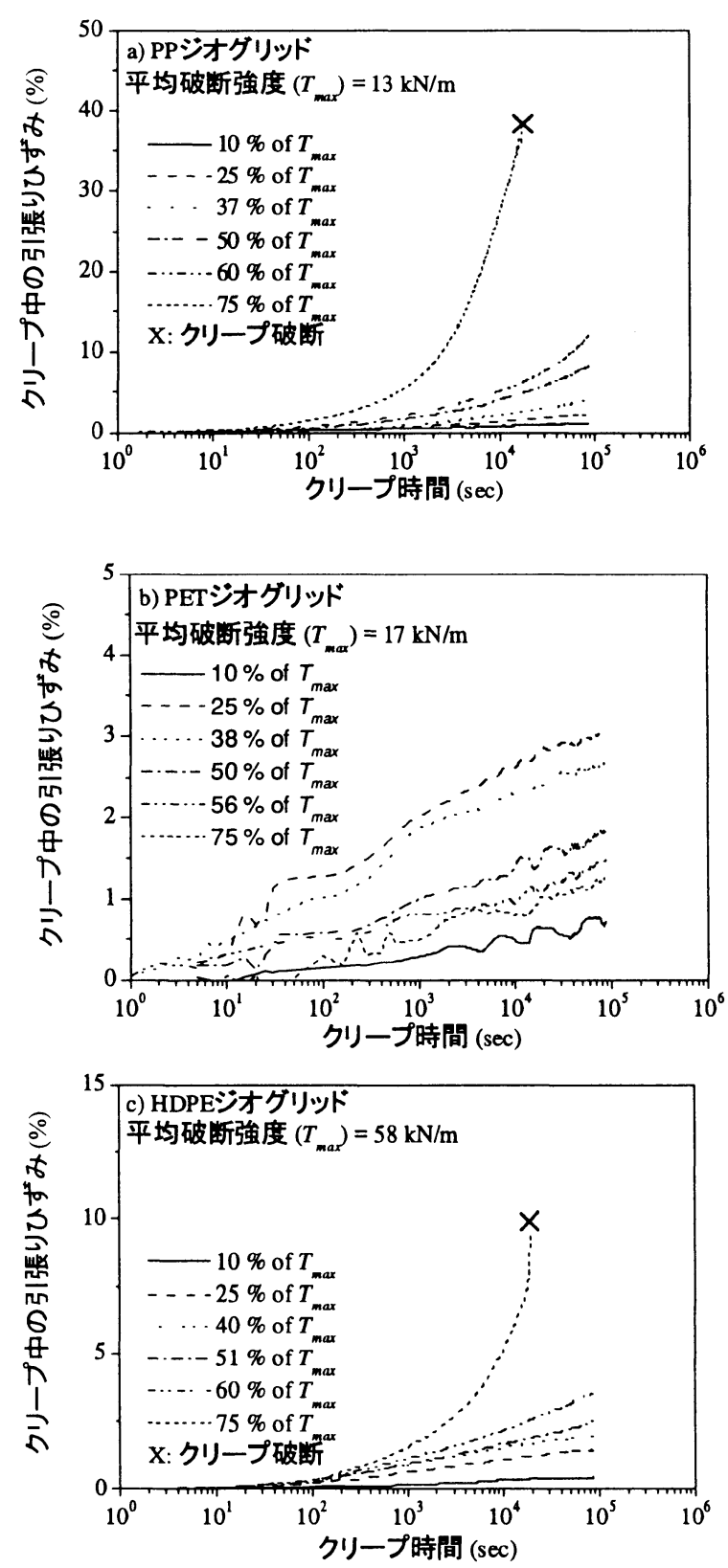

図7 クリープ中の引張りひずみ時刻暦 
（3） PET、HDPEジオグリッドの最大引張りひずみは供 試体の縦横比には影響しない。

（4） PPジオグリッドの長手方向のリブ数は最大引張り ひずみに影響を与える。

（5） PP、HDPEジオグリッドの引張り変形強度特性に対 するひずみ速度の影響は大きいが、PETジオグリッ ドに関しては小さい。

（6）クリープ試験において、PPジオグリッドはPETジ オグリッドと比較すると高い延性を持つ。

（7） 応力緩和試験におけるPPジオグリッドの引張り力 の緩和速度は、PET、HDPEジオグリッドと比較す ると大きい。

（8）クリープや応力緩和試験後のPP、PET、HDPEジオ グリッドの引張り強度は、クリープや応力緩和試 験を受けない試験体の平均引張り強度とほぼ同じ 值を示した。つまり、地震時の補強材設計強度の 算定においては、クリープ低减係数を使用すると 補強材強度を過小評価する可能性が高いことが示 された。
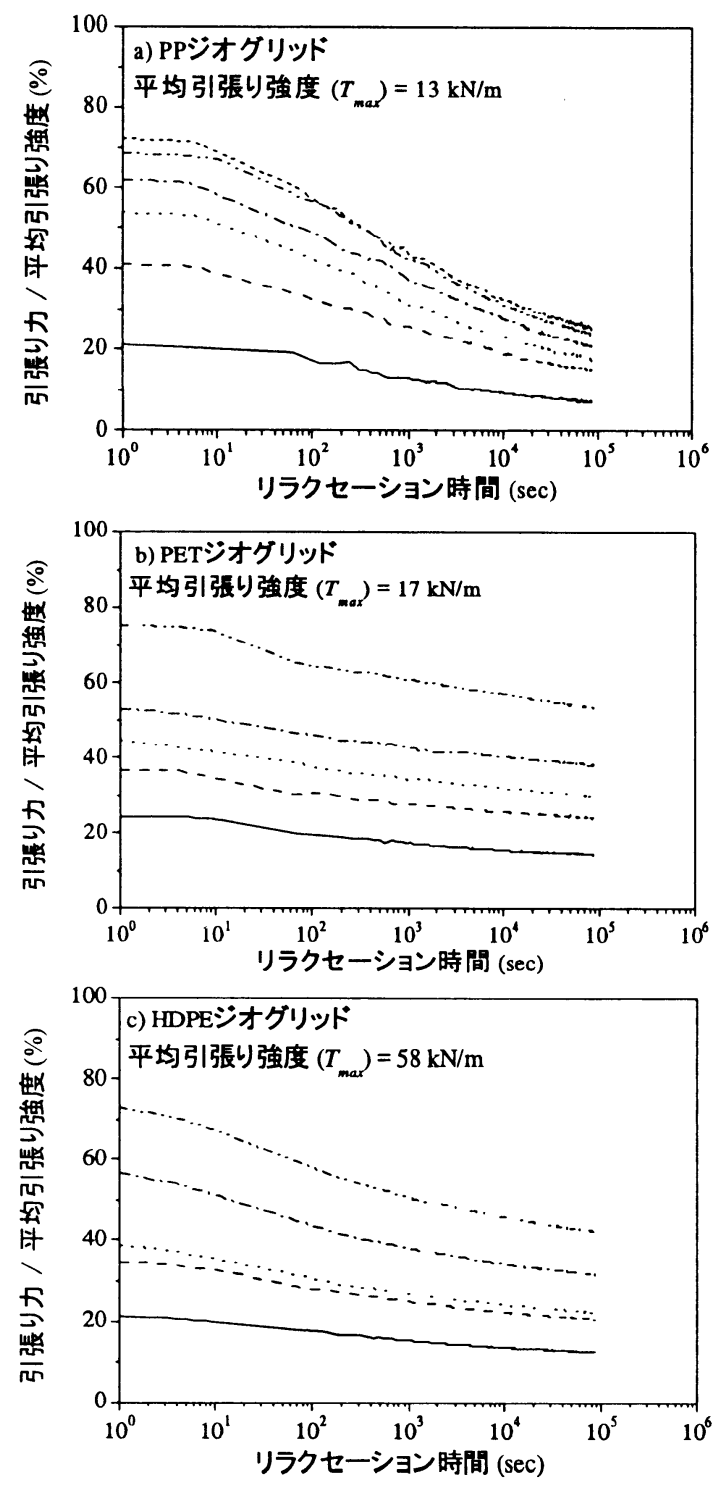

図8 リラクセーション中の引張りカ比時刻暦
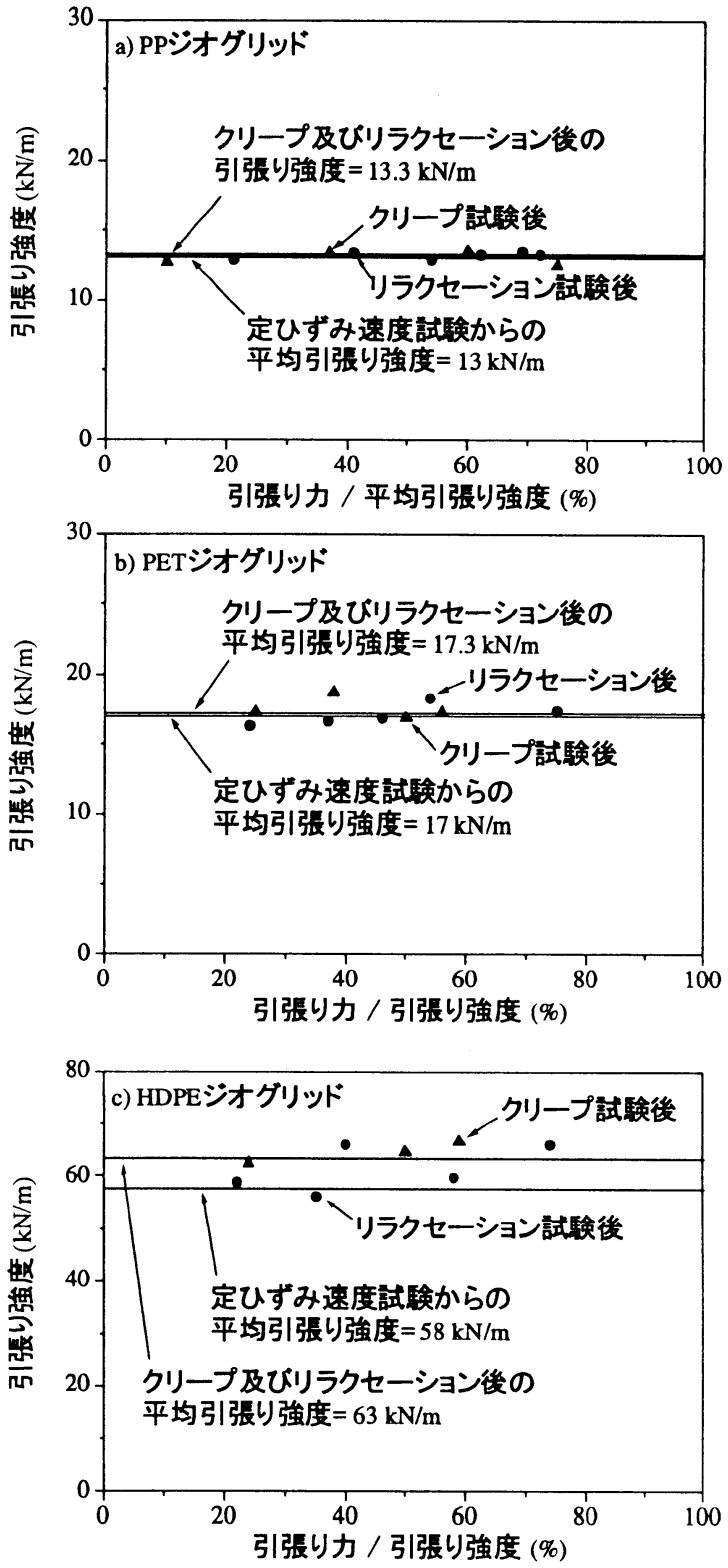

図9 クリープ及びリラクセーション試験後の定ひずみ 速度試験

\section{7. 参考文献}

1) MoGown, A., Andrawes, K. Z., and Kakir, M. H., 1982, "Load extension testing of geotextiles confined in soil", Proceedings of the Second Intemational Conference on Geotextiles, Vol. 3,pp. 793-798.

2) El-Fermaoui, A. and Nowatzki, E., 1982, 'Effect of confining pressure on performance of geotextiles in soils", Proceedings of the Second Intemational Conference on Geotextiles, Vol. 3, pp. 799-804.

3) Jewell, R. A. and Greenwood, J. H., 1988, 'Long term strength and safety in steep soil slopes reinforced by polymer materials" Geotextiles and Geomembranes, Vol.7,pp. 81-118.

4) Jewell, R. A., 1992, "Strength and deformation in reinforced soil design" Proceedings of the Fourth Intemational Conference on Geotextiles, Geomembrones and Related Products, pp. 913-946.

5) MoGown, A., Andrawes, KZ. and Yeo, KC. (1984) 'The load-strain- 
time behaviour of Tensar geogrid" Polymer Grid Reinforcement, Thomas Telford, 1985, Proceeding of a conference held in London, pp.11-17.

6) Greenwood, J. H., 1990, "The creep of geotextiles", Proceeding of the Fourth Intemational Conference on Geotextiles, Balkema, Vol.2, pp.645650 .

7) Bemardi, M. and Paulson, J., 1997, "Is creep a degradation phenomenon?', Mechanically Stabilized Backfil, (Wu.J.T.H. eds), Balkema, pp.289-294.

8) Orsat, P., Khay, M and MoCreath, M., 1998, "Study on creep-nupture of Polyester Ttendons: Full scale tests" Proceedings of the Sixth Intemational Conference on Geasynthetics, Vol. 2, pp.675-678.

9) Greenwood, J. H., Kempton, G. T., Watts, G. R. A. and Bush, D. I., 2000, "Twelve year creep tests on geosynthetic reinforcements", Proceedings of EuroGeo 2000,pp.333-336.

10) Greenwood, J. H., Jones, C. J. F. P. and Tatsuoka, F., 2001, "Residual strength and its application to design of reinforced soil in seismic areas", Proceedings of the Intemational Sympasim on Earth Reinforcement (Ochiai et al, eds), Balkema, Vol.1,pp37-42.

11) Voskamp, W., Vliet, F. and Retzlaff, J., 2001, "Residual strength of PET after more than 12 years creep loading" Proceedings of the Intemational Symposium on Earth Reinforcement (Ochiai at al, eds), Balkema, Vol.1, pp.165-170.

12) Tatsuoka,F., Santuoci de Magistris,F., Hayano,K, Momoya, $Y$. and Koseki,J. (2000): "Some new aspects of time effects on the stress-strain bethaviour of stiff geomaterials", Keynote Lecture, The Geotechnics of Hard Soils - Soft Rocks, Proc. of Second Int Conf. on Hard Soils and Soft Rocks, Napoli, 1998 (Evamgelista and Picarelli eds.), Balkema, Vol.2, pp1285-1371.

13) UchimuraT, Tatsuoka,F, Tateyama,M. and Koga,T. (1998), "Preloadedprestressed geogrid-reinforced soil bridge pier", Proc. $6^{\text {th }}$ ht Conf. on Geosynthetics, Atlanta, pp 565-572.

14) Leshchinsky, D., Dechasakulsom, M., Kaliakin, V. N. and Ling, H. I, 1997, "Creep and stress relaxation of geogrid", Geosynthetics Intemational, Vol. 4, No. 5,pp.463-479.
15) Shrestha, S. C. and Bell, J. R, 1982, "A wide stuip tensile test of geotextiles" Proceedings of the Second Intemational Conference on Geotextiles, Vol3, pp. 739-744.

16) ASTM D 4595, "Standand test method for tensile properties of geotextiles by the wide-width strip method", American Society for Testing and Materials, West Conshohocken, Pennsylvania, USA.

17) Leshchinsky, D. and Fowler, J., 1990, "Laboratory measurement of loadelongation relationship of high-strength geotextiles", Geotextiles and Geomembranes, Vol.9, pp. 145-164.

18) Jones, D., 2000, "Wide-widh geotextile testing with Video Extensometer, Grisp, Clamps, Clamping Techniques, and Strain Measurement for Testing of Geosynthetics, ASTM STP 1379, PE. Stevenson, Ed.,pp.83-88.

19) Bathurst, R. J. and Cai, Z., 1994, "In-isolation cyclic loadextention behavior of two geogrid", Geosynthetics Intemational, Vol. 1, No. 1, pp. 1-19.

20) Boyle, S. R., Gallagher, M. and Holtz, R. D., 1996, "Influence of strain rate, specimen length and confinement on measured geotextile properties", Geosynthetics Intemational, Vol. 3, No. 2,pp. 205-225.

21) Voskamp, W. and Van Vilet, F., 2001, "Variation in creep rate at constant loading of PET geogrid strapping", Proceedings of the Intemational Symposium on Earth Reinforcement (Ochiai at al., eds), Balkema, Vol.1, pp.159-164.

22) Soong.T.-Y., Lord, A. E. and Koemer, R. M., 1994, "Stress relaxation behavior of HDPE geomembranes", Proceedings of the Figth Intemational Conference on Geotextiles, Geomembranes and Related Products, pp. 1121-1124.

23) Thomton, J. S., Allen, S. R and Thomas, R. W., 1997, "Approaches for the prediction of long term viscoelastic properties of geosynthetics from shot term tests", Proceedings of Geasynthetics'97, Vol. 1,pp. 277-291.

24) Thomton, J. S., 2001, "Characterization of short and long term creop and relaxation properties of a polypropylene geogrid" Proceedings of Geosynthetics Conference 2001,pp.835-845.

\title{
TIME-DEPENDENT DEFORMATION AND STRENGTH CHARACTERISTICS OF GEOGRIDS LUE TO VISCOUS PROPERITES
}

\author{
Masahiro SHINODA, Richard, J. BATHURST, Fumio TATSUOKA and Katsumi HORII
}

One of the main uncertainties in the design of permanent reinforced soil structures is the strength and deformation characteristics throughout the design life of polymeric reinforcement under load in the backfill. The current design practice focuses primarily on the creep deformation and the design tensile rupture strength is determined by using a relatively large creep reduction factor. To have a better insight into the time-dependent strength and deformation characteristics of polymer geogrid, in total 34 creep and stress relaxation tests were performed at various tensile load levels, each lasting for 24 hours, by using polypropylene (PP), polyester (PET) and high density polyethylene (HDPE) geogrids. A series of constant rate of strain (CRS) loading tests was performed on specimens that had been subjected to creep or relaxation loading. The tensile strength after creep and relaxation loading of each geogrid was essentially the same value as the one obtained from a monotonic CRS tensile loading test before the creep or stress relaxation test. This result shows that it is not necessary to use a creep reduction factor when determining the design tensile strength for prototype reinforced soil structures subjected to seismic force. 